\title{
江戸の元地と代地に関する研究 \\ A STUDY ON THE ORIGINAL LOT AND THE SUBSTITUTE LOT OF EDOTOWN
}

\author{
李 佶 勲* \\ Kilhun LEE
}

\begin{abstract}
This study is to consider the trend of the substitute Lot which was given to the town (to take up the subject) to protect against fire during the Genroku period - Kyoho term.

This paper consists of two contents: 1 . The urban special configuration of the protection space against fire, the original lot and the substitute lot using Kanda Sakumacho ,2. The social structure of the original lot and the substitute lot through "Noh Play Look" and the labor (tax) of Minamidaikucho. As for the relation between original lot and the substitute lot, the social structure and the urban spatial configuration consist of different layers. Townspeople of the original lot and the substitute lot did their labor and enjoyed "Noh Play Look" together beyond the urban spatial structure of the town. The space and society by the original lot and the substitute lot were accomplished by different mechanism, but it is certain that Edo city was accomplished by these.
\end{abstract}

Keywords ; Edotown, the Protection Space Against Fire, the Original Lot, the Substitute Lot, labor, Noh Play, Sakumacho, Minamidaikucho

江戸，火除明地，元地，代地，役，能，佐久間町，南大工町

\section{1. はじめに}

『御府内沿革図書』をみると江戸町中には「代地」が存在する。 「代地」とは公収された土地の代わりに与えられる土地のことであ るが、いったん代地を与えられと、その土地は「○○(従来の町名) 代地」と呼ばれるようになる。そして移転する前の土地という意味 で、元地という観念がうまれる。本稿では、明地にするために公収 された町に与えられた代地を対象にし、元禄期一享保期中いかなる 動きが見られるかを考察する。町地が火災で明地になり、代わりに 代地が与えられるという土地の入れ替えを追究することで、江戸の 巨大都市化の一端を探ることが本稿の目的である。

本稿の分析は以下の二つからなる。第一、神田佐久間町の事例に みる明地と元地と代地の空間構造の分析、第二、南大工町の役と「御 能拝見」からみる元地と代地の社会構造の分析によって構成される。 江戸の明地による元地と代地に関する研究は史料の限界もあり、 ほとんど行われていないが、吉田伸之氏は『近世巨大都市の社会構

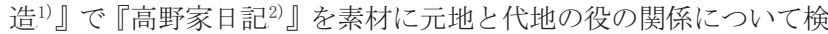
討している。本来、代地で元地の役が継続されるが、享保七年代地 の公役は元地ではなくその町が勤めることになる。ところが、例と してあげている松川町では、役が消滅することなく継続しているこ とがわかる。役負担をめぐる元地と代地の関係は、ついに断ち切ら れることなく続いていたと結論づけている。その他、土地所有 ${ }^{3)} や$ 税に関する研究 ${ }^{4)}$ は蓄積されている。

本稿は『旧幕府引継書、享保撰要類集一明地之部 ${ }^{5)}$ 』、『安永三年 江戸町鑑 6)』、『江戸町触集成』、『御府内備考』の分析により、佐久
間町を素材に明地による元地と代地の都市空間構造を、また南大工 町を素材に役の検討、及びこれまで言及されてこなかった「御能拝 見」というイベントを通じて元地と代地の社会構造について明らか にしたい。

\section{2. 史料について}

本稿で用いる史料は、『旧幕府引継書、享保撰要類集一明地之部』、 『安永三年江戸町鑑』、『江戸町触』、『御府内備考』の 4 点である。

おもに引用している『旧幕府引継書、享保撰要類集一明地之部』 は国立国会図書館所蔵の史料で、江戸幕府官衙の諸記録が幕府崩壊 にさいし東京府庁に引き継がれたものである。評定所・寺社奉行・ 作事奉行所等々が含まれているが、その大半は町奉行所関係である 7)。その中、本稿で用いた『享保撰要類集一明地之部』は享保期に おける明地にかかわる書類で、町奉行が明地を管理するために作成 したと思われる。明地と代地が定められた経緯は書かれていないが、 定められた結果は事実で、明地と明地から生じる代地を探るには適 切な史料であることはいうまでもない。

その外、『安永三年江戸町鑑』は安永 3 年 (1774) に町奉行所で作 成されたもので、当時における江戸市中全体の課税内容、町の沿革、 支配名主などが判明するものとしては唯一であり ${ }^{8)}$ 、本稿で述べて いる享保期にもっとも近い時期の史料でもある。その中、本稿では 当町の課税や町の沿革において引用している。『江戸町触集成』は昭 和 39 年から昭和 41 年にかけて刊行した『正宝事録』(日本学術振興 会刊）を底本とし、「東照宮本町触」などをもって補い、また、「撰 
要永久録」「町方日記」によって新たな対校を行った史料で、本稿 では、役と「御能拝見」の詳細な分析のため用いる。『御府内備考』 は、江戸幕府が編集した江戸の地誌で、文政 9 年（1826）幕府が編 集した『御府内風土記』の編纂の備考として整理された資料集であ る。編纂された資料という弱点はあるが、他史料に見えない町の沿 革が書かれているため、検討の上、引用することにする。

\section{3. 明地による元地と代地の空間構造}

江戸は火災都市と呼ばれるほど火事が多かった。度重なる火事を 経て江戸は防災都市としての面貌を整えていく。そんななか、火事 で類焼した町は幕府に公収され、火除明地になり、そのかわりに代 地を与えられた[史料 3]。こうして江戸町中は火災を契機に設けら れた明地と代わりに与えられた代地、その他、元地、残地、蔵地な どが散在する複雑な都市になっていく。本節では、佐久間町を素材 に明地と元地と代地の空間構造一土地と建築一について考察する。

\section{3-1. 神田佐久間町における明地・元地・代地の形成過程}

以下の二つの史料を取り上げながら、元禄期から享保期にかけて の神田佐久間町の変化を探る。

【史料 $1^{9)}$ 】(安永 3 年作成)

$$
\text { 一神田佐久間壱町目名主 仁左衛門 }
$$

小間京間式拾壱間壱尺 但、公役銀相勤申候、

右佐久間町壱町目之儀者、河岸元地より代地迄者凡北之方江八拾間 隔り有之候得共、古来之裹行武拾壱間五尺九寸二而右河岸通二有之 候処、先年御用地二被召上、不残北之方江跡しさり二代地被下置候、 右元地二相離候儀町人共一同難儀仕候二付、有来間数右裏行之内河 岸元地江拾間通御割替奉願候儀二御座候得者、一屋敷之者二屋敷二 相成候間、代地与申唱、其地所御尋之節計申上候、其外之義者代地 与申唱者不仕候、依之右公役銀相勤候間数も前書元地計八間数二而 相勤候義二御座候、（傍線筆者、以下同じ）

【史料 $2^{10)}$ 】

佐久間町一丁目（中略）

一上納地四百八拾八坪六合三夕

右は町内河岸通地尻二有之、長屋并前書町家迁替二申上候通、享 保一九寅年三月廿八日、町内河岸通町屋奥行短く辨利悪敷候二付、 是迄拝借裏行三間通の上、三尺増地被仰付、三間半通拝借地二被成 候様、尤上納金差上可申旨奉願、同十二月廿四日大岡越前守様御 番所二而願之通仰付、翌二十卯年二月廿三日御地渡有之候、(後略)

[史料 1 ] ・ [史料 5 ] によると、佐久間一丁目は享保 4 年 (1719) に 火除明地として公収され、北方に代地を与えられる。その際、北側 にあった町屋も北側に後退させられている。佐久間一丁目の町人は 河岸地で材木にかかわる仕事 ${ }^{11)}$ に従事していたため、代地が河岸と 80 間も隔たり、難儀していると訴えている。そこで、『御府内備考』 によると享保 10 年、代地の 10 間と元地の河岸通りの 10 間を交換し ている。[史料 3 ] によると、西の方の水野隼人正が明地になったた め、御成りの節、見通しになり用心によくないため、元地河岸通り 10 間に 3 間の拝借地を願っている。その拝借地 3 間が短くて不便で あるので、 3 尺を増やしてもらう状況がみられる（［史料 2 ］の傍線 部）。代わりに、明地であったこの 3 間半の土地は上納地になる。
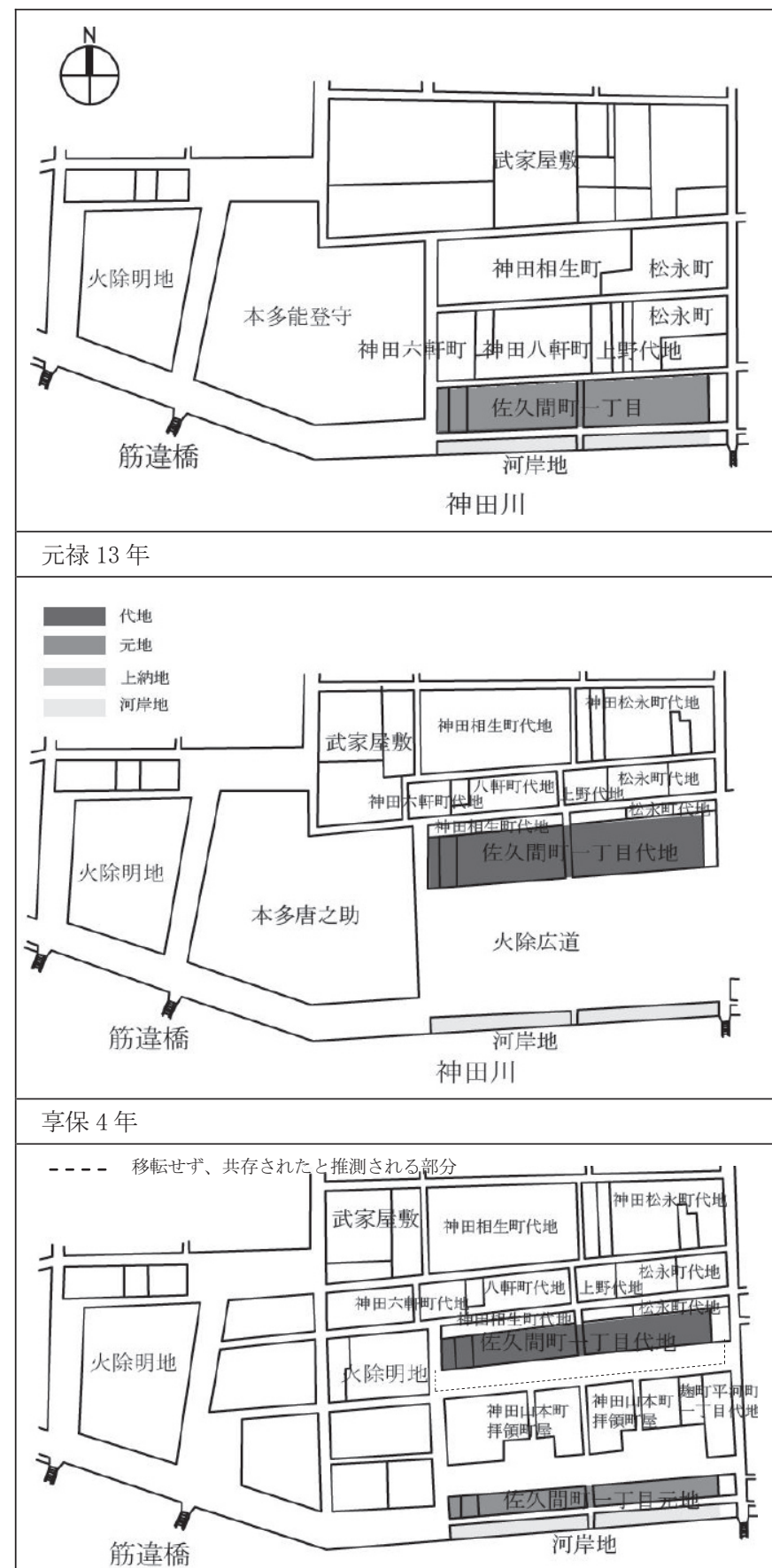

神田川

享保 13 年一 15 年

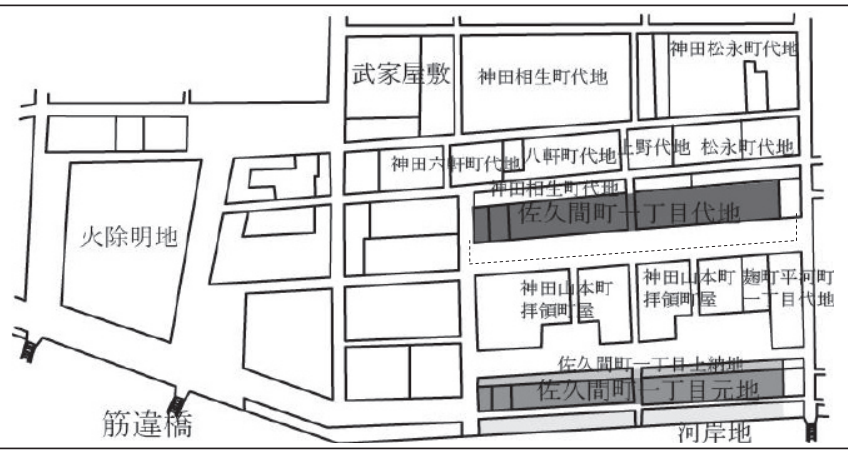

享保 16 年一 20 年

図 1 佐久間町一町目の明地・元地・代地 (『御府内沿革図書』を基 こして分析にあたる年代の地図を取り出し、佐久間町一丁目を対象に して明地・元地・代地・上納地を書き加えた地図) 
その結果、佐久間一丁目は元地と明地、代地、上納地、河岸地で構 成されることになる。図 1 は元禄期から享保期における佐久間一丁 目による周辺の動きを表している。

[史料 1]で注目したいもう一点は、代地の拾間と替えた河岸通り の 10 間である。一屋敷の者が二屋敷になり、すなわち代地の 10 間 と河岸通りの元地の 10 間を同じ人物が占めていたことがわかる。と ころが、公役銀は元地のみ勤めればよいと書かれている。沿革図書 や史料に「移転」の記載があっても、実際には両地が使用されてい たことが窥える。

\section{3-2. 土地と建築}

ここでは、以下の史料から佐久間町周辺の都市空間構造を読み取 る。

【史料 $3{ }^{12)}$ 】（享保 11 年一敦保 12 年作成）

神田佐久間町

河岸通竹木薪差置候願之儀申上候書付、 神田佐久間町 壱町目武丁目三町目四丁目 家持 町人共

右之もの共相願候者去ル亥子両年二御用地二被 召上跡しさりニ 代地被下置候、其節武町目より四丁目迄之儀元地之内二而八間通 蔵地御残被下置、壱町目之儀者不残跡しさり二罷成候故壱町目之 もの共去暮相願、代地拾間通差上、河岸元地江御引替被下置候二 付、塗屋造り二仕候、然処右町々河岸通商売之竹木薪差置候儀不 罷成候故、借地之もの共他所江引越過半明地二罷成、町役等も難 相勤身本二而至極困窮仕候、依之此度右蔵地河岸通江商売之竹木薪 少々宛差置候儀御免被成下候様相願申候、尤竹木者立置薪之儀八 高严三尺限り差置万一出火等御座候而茂、竹木薪江一切火移シ申 間鋪旨相願之候右吟味仕候処、河岸通商売之竹木薪等差置不申候 而者、商売無御座、夫故地借等も無之迷惑仕候段相違無御座候、 (中略) 九月 大岡越前守

右書附絵図壱枚相添、午九月廿六日水野和泉守殿江上儿、

（付紙）「伺之通可申付旨被仰渡奉畏候＼cjkstart午十月三日大岡越前守」 佐久間町町人共居宅裏拝借地之儀申上候書付、

覚

佐久間町壱町目 家持町人 拾九人

右之者共代地之方拾間通り差上、元地河岸通り二而裏行拾間叙家 造り之儀去午十月願之通被 仰付候故、段々家作仕候、就夫同所 西之方水野隼人正上り地跡町屋二被 仰付候、残り過半明キ地二 而、御成御道筋上り右町人共塗家裏通御目通二罷成、其上代地之 方より者、余程隔用心等悪敷御座候間何卒別紙絵図之通塗家裏通 三間長町並二拝借地奉願候、尤惣迴り竹矢来二成共又者板塀二成 共可仕旨相願申候、右町人共願之通可被 仰付候哉奉伺候、尤障 儀無御座候併板塀之儀者如何二御座候間弥可被 仰付候八々、竹 矢来二 $(\triangle)$ 申付可然奉存候、則絵図壱枚奉懸御目候以上、

$$
\text { 二月 大岡越前守 諏訪美濃守 }
$$

$\triangle$ 下ヶ札

木挽町四丁目町人共儀、去々巳年願之通、元地江御返シ被下候処、

裏之方明地不用心二付、九尺通り竹矢来之儀相願候処、願之通

被 仰付候例も御座候、(中略)

未三月廿日日岡越前守 諏訪美濃守
【史料 $4^{13)}$ 】(享保 13 年作成)

佐久間町弐丁目三丁目町人共町並願之儀申上候書付 神田佐久間町武丁目町人共 同町三町目町人共

（前略）蔵造之間九尺宛明ヶ候而家作仕候、此九尺宛之明キ地相 止入蔵造建続候椂二仕度奉存候、(中略)、右場所明地之内、今度 麦町平河町代地二茂相障不申候、佐久間町武丁目河岸蔵造町屋願 之通壱町目並二跡志さり其上蔵造之間、九尺宛之明キ相止入建続 二罷成何之相障候儀無御座候、(中略)

六月 大岡越前守

$\triangle$ 下ヶ札（付紙）

「此蔵之間九尺宛明キ有之候儀者、先年御用地二上候節、元地之内 二而蔵造町屋二相願候二付、蔵と蔵との間九尺宛明ヶ候様二被 仰付、只今迄九尺宛明キ有之候、(後略)、」

【史料 $5^{14)}$ 】(享保 5 年作成)

（前略）享保四亥年同五子年明地二被 仰付候

柳原和泉橋外

佐久間町壱町目

同武丁目

松永町明地

上野町之内

右明地内二平川町壱丁目代地芝新馬場同朋町代地其外御弓師择領 屋鋪等被 仰付候（後略）、

[史料 3]、[史料 4]、[史料 5 ] から注目されるのは以下の六点で ある。

（1）火除地として町地が取り上げられた際、代地が与えられたこ と。([史料 3 ]により)

（2）代地に移転しても、元地に蔵地を願い出て、元地の一部を確 保していたこと。([史料 3$]$ により)

（3）代地の一部分を差し上げ、それと引き換えに元地の一部を取 り戻したこと。([史料 3$]$ により)

（4）蔵地での建築はいかなるものだったのか。（[史料 3]、[史料 4]により)

（5）代地から元地一戻った事例の存在。([史料 3 ]により)

（6）火除明地に他町の代地とされたこと。([史料 4]、[史料 5 ] により)

（1）と（2）からは火除地という明地が設定されたことによっ て生じる代地、元地、蔵地、上納地の存在が窥える。特に河岸通り にあり、河岸で仕事をしていた町人は代地と河岸地間が遠いという 理由をあげ、元地での蔵地の許可を願っている。ここからは元地か ら代地一移転しても河岸の使用権は引き続き与えられていたことが 窥える。また（2）では用心の理由をあげながら、3 間半の上納地 の許可を願っている。結局、明地は替地である蔵地や上納地に占め られていく。

（3）からは代地と元地の間の取引が見られる。蔵地を願いなが ら代地の 10 間を返納し、元地の 10 間と取り替えようとする。3-1 で前述したように返納すると言っていた代地の 10 間はそのまま使 い役も勤めなくて済んだと思われる（[史料 1] の傍線部により証 
明される)。

（4）では蔵地に建てられた建築の様子が窺える。まず、火除明 地に蔵地を許可するため、塗家造りにすることが条件であった。ま た、高さ 3 尺限りの竹木と薪積み、及び叙家 ${ }^{15)}$ 裏通りに用心のた め竹矢来や板塀を願い、許可が出される。先年、蔵と蔵の間は九尺 $(272.7 \mathrm{~cm})$ ずつ空けて建てるという触が享保 13 年（1728）になく なっており、蔵が続いて建っている姿が予想される。

（5）佐久間町以外の地域であるが、元地一戻った例が確認でき る。最後に（6）では、火除明地が他町の代地とされ、また江戸町 中は再編されたことが窺える。

以上（1）〜（6）を通じて、明地に指定される際に生じる様々 な都市空間と建築について検討した。このように様々な形態の土地 が入れ替わりながら、江戸町中の都市空間は形態だけではなく、そ の性質も変えていた。例えば、町人地 $\rightarrow$ 明地、大名屋敷 $\rightarrow$ 代地 (町 人地)、明地 $\rightarrow$ 蔵地、また明地 $\rightarrow$ 上納地といった変化がみられる。土 地の用途の変化は所有者をはじめ役及び税の変化をもたらすことに なる。このような現象は火事という災害を契機に、火除地という幕 府が意図している都市インフラの論理と町人の所有意志が衝突しな がら現れたと思われる。

\section{4. 元地と代地の社会構造一江戸南大工町を例として}

『安永三年江戸町鑑』によると品川を含んだ 22 名主番組の下、 1708 の町の中には 137 の代地が存在した。しかし江戸町中に散在し ていた代地の実態は知られていない。元地から代地に引っ越しして きた町人たちの生活はいかなるものだったのか。本節では、南大工 町の成立と代地の成立、さらに役をめぐる元地と代地の関係、「御能 扯見」をめぐる元地と代地の関係について検討寸る。

\section{4-1. 南大工町の元地と代地}

以下の史料からは元大工町と南大工町の空間の動きが窺える。

【史料 $6^{16)}$ 】(安永 3 年作成)

一南大工町壱町目・武町目

（附札）「近来喜多村江八南大工町与計一町之銘日二書出申候、」 小間京間九拾六間武尺九寸五分

但、内九拾式間五尺七寸五分者御国役大工相勤申候、

三間三尺七寸者南大工町与唱候得共、元来松倉町之切レ地二 而南大工町之御役者相勤不申、元地松川町江相勤申候、

右町内之儀、先年元大工町南側御用地二被召上、代地者桶町後江 広小路二而被下置、其代地 7 南大工町与唱候得共、右代地二而者 六拾九間四寸五分不足二付、右不足地之分者、名主孫左衛門支配 当時音羽町内二而小間武拾四間壱尺、当時小松町之内二而武拾六 間三尺五寸三分、又兵衛支配当時福島町之内二而小間九間式尺武 寸四分、主計支配当時正木町之内二而小間四間六尺四寸三分、右 之通四ヶ町二而被下置候、尤御国役大工者割合を以四ヶ所より南 大工町江差出申候、且又南大工町入組有之候松川町切地之儀者当 時南大工町与唱、御役者元地松川町江出銀仕候而相勤申候、

[史料6]と[史料8]からは、南大工町が元大工町の代地であることが 判明する。元大工町は元禄三年 ${ }^{17)}$ 、町の南側をご用地として公収され、 桶町の南側にある広小路に代地を与えられ、南大工町と称した。と
ころが、元大工町がここに代地を与えられた際、面積が不足したた め、「足し地 ${ }^{18)} 」$ とて正木町、福島町、小松町、音羽町の 4 箇所 が追加される。この 4 箇所は元禄三年、堀の埋立地で周辺の町の「足 し地」として成立した。元大工町、南大工町、正木町、福島町、小 松町、音羽町は本来一町であったが、明地として公収されたことで 空間的に 6 箇所に分れることになる。この六つの町は [史料 7] から 見えるように各々別の名主の支配に置かれている。都市空間と支配 が分離した町人の生活はどのようなものであったか。

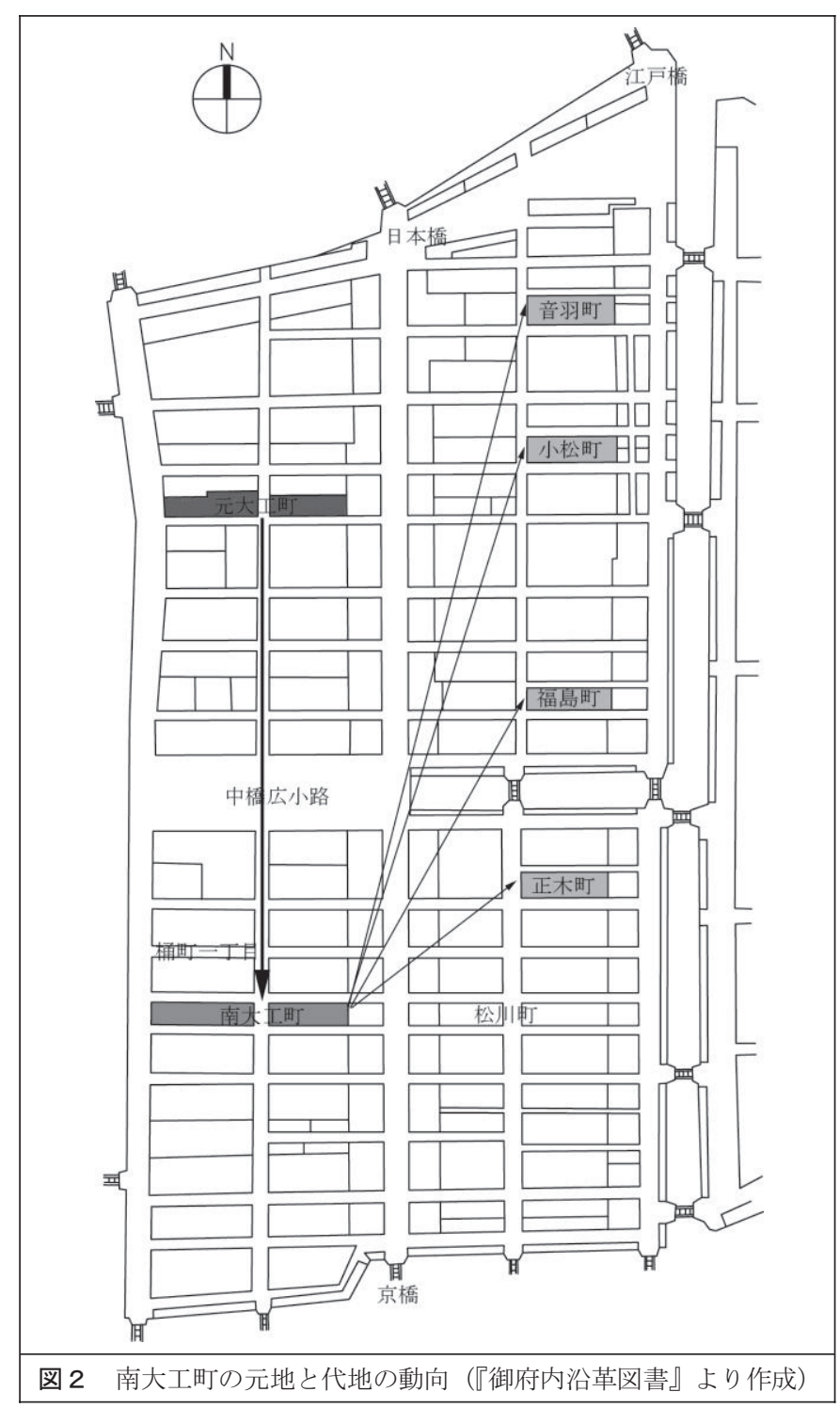

\section{4-2. 役からみる元地と代地}

以下、享保 7 年 (1722) に出された町触には元地と代地の間での 役が読み取られる。

\section{【史料 $7^{19)}$ 】(享保 7 年作成)}

覚（前略）

一只今迄所々代地之分、大方元地江役相勤候、自今八元地江役相 勤候儀相止、其町二而役可相勤候事

一只今迄元地江役相勤候内、元地国役町之分八、只今迄之通、元 地江国役可相勤候事 
一元地江役勤候内、年貢差出候者、只今迄之通元地江役可相勤候 事 (中略)

（付紙）「右割付、左二有之手前支配之分追加」

一音羽町惣間数京間三拾六間九寸五分 内京間廿四間九寸五分 国役

壱ケ年拾五篇勤之積り

$$
\text { 此人足三拾七人半 但五間口壱人役 }
$$

$$
\text { 此賃銀七拾五多 但人足壱人銀武多以、 }
$$

右間数之内、京間廿四間九寸五分は元地南大工町江国役相勤、 残京間拾二間より壱ヶ年分之町人足賃銀を以、書面之通上納可致 候、此余は如何様之御用二而も、自今役人足不相懸筈二候、賃銀 之儀は壱ヶ年三度二上納可致候、以上

一小松町惣間数京間四拾式間壱尺八寸

内京間武拾六間壱尺八寸 国役

壱ヶ年拾五篇勤之積り

$$
\begin{array}{rr}
\text { 此人足四拾五人 } & \text { 但五間口壱人役 } \\
\text { 此賃銀九拾多 } & \text { 但人足壱人武多宛 }
\end{array}
$$

右間数之内、京間廿六間壱尺八寸は元地南大工町江国役相勤、 残京間拾六間八分より壱ヶ年分之町人足賃銀を以、書面之通上納 可致候、此余は如ヶ様之御用二候共、自今役人足不相䀣筈二候、 賃銀之儀は壱ヶ年三度二上納可致候、以上、（後略）

享保七年に役にかかわる触が出される。その中で、元地と代地に 関する項目が[史料 7 ] である。内容は以下の三点である。（1）今ま で代地では元地に役を勤めていたが、今後はその町（代地）に役を 勤める、（2）国役の場合、以前の通り元地に役を勤めること、（3） 年貢の場合、以前の通り元地に役を勤めることが触れられている。

本項では、南大工町と他の代地の役を検討することで、元地と代 地の関係を明らかにする。

[史料 6 ] と [史料 7 ] の傍線部を見ると元大工町が南大工町の代地 として与えられたのは京間 92 間 5 尺 7 寸 5 分で、69 間 4 寸 5 分不 足していることが分かる。そこで「足し地」として、音羽町内に小 間 24 間 1 尺、小松町之内に 26 間 3 尺 5 寸 3 分、福島町内に小間 9 間 2 尺 2 寸 4 分、正木町内に小間 4 間 6 尺 4 寸 3 分を再び与えられ る。町触によると、元大工町は国役町であって、代地でも元地に対 して、国役を勤めることになる。[史料 7 ］からは「足し地」は南大 工町に割合通りに役を差し出していることがわかる。本来の元地で ある元大工町ではなく、第一代地である南大工町に差し出すことに 注目したい。元大工町と南大工町は国役町にもかかわらず、役の側 面では分離し、二つの町になったことが考えられる。

ここでさらに複雑になるのは、南大工町の 3 間 3 尺 7 寸は松川町 の切地で松川町に公役を勤めていた点である。町触によると、公役 であれば、元地に勤める必要が無くなったにもかかわらず、元地に 出している現象がみられる。

図 3 に南大工町をめぐる役関係を図示した。享保七年、役につい て町触が出されているが、実際、元地と代地では触とは異なる役の 勤めが現われている。役を決めるのは、幕府の町触でも、名主の支 配でも、町の領域でもなく、その中で住んでいた町人同士であった 可能性が示唆された。元地と代地の間で町人達の結束力が町という 空間を超えて社会構造を守ろうとしていたことがわかる。

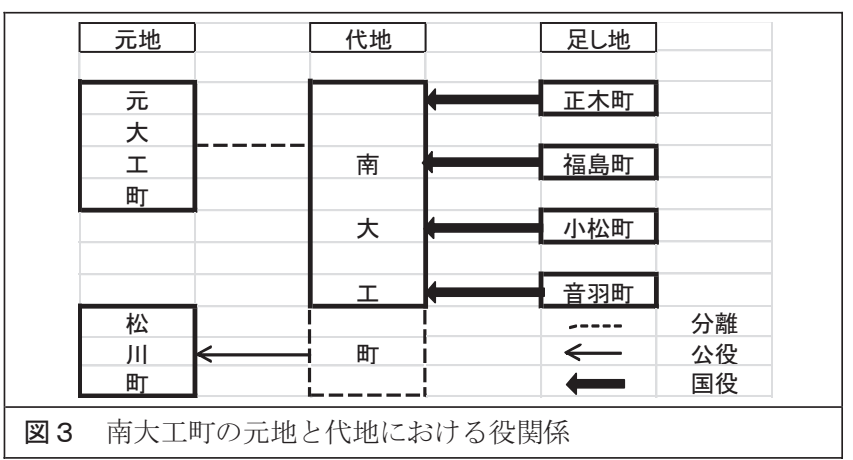

\section{4-3.「御能拝見」からみる元地と代地}

江戸は幕府から町人まで遊びを楽しんでいた。この中で挙げられ るのが「能」で、寛永十一年 (1634)、幕府は江戸の主な町の町人を 城内の庭に集め、銀五○○○貫を配った。誰にでも配られたわけで はなく、江戸に二○年以上居住していること、世帯主であること、 などいくつかの条件があった。場所は江戸城内大広門の舞台で、時 間は午前八時から、昼夜入れ替え制で大概夜の九時頃までであった 20)。

近世の町人の遊びは「御能」以外にも多様であるが、本稿ではと りわけ「御能拝見」を取り上げる。「御能拝見」は幕府が主体で町人 を江戸城大手の広庭まで招待して行われた行事でこれが持つ意味合 いは大きいのである。「御能拝見」は幕府から町人が楽しめた遊びと しての意味にとどまらず、近世江戸において社会的、文化的、政治 的にも意味があるともいえる。本節では、このように江戸町人にと って大イベントであった「御能拝見」が南大工町ではどのように行 われたのかを検討する。

\section{【史料 $8^{21}$ 】(宝暦 13 年作成)}

宝暦十三年五月廿二日 喜多村二而年番名主江被申渡 御能拝見二罷出、御銭被下候町々之内、元地之人数江代地之人数加 り、拝見二出候分并訳二而も有之、古来より他町之人数之内江加り、 拝見二出候町々も有之候哉、尤右二準し候類二而も有之候分、 右之趣御能拝見二出候町々江斗、組合中不洩様被申継、有之分は 書付二致、来廿五日迄二銘々可被差出候、尤無之分は返答書、組 合切二年番江取集义、是亦廿五日迄可被差出候、(中略)

例有之処より書付差出候儀承り書留

以書付申上候、(中略)

一南大工町之儀は年月不相知、先年元大工町壱町目武町目共二両 側御用地二被召上、為代地桶町後広小路二而被下置、夫より南大 工町之唱申候、然処右代地不足故、足シ地正木町、福島町、小松 町、音羽町右四ヶ所之内二而、間口六拾四間武尺武寸、裏行拾式 間被下置、尤御能拝見人数礼之儀は高三拾四人二而、元大工町南 大工町壱紙二被下置候而、右之内壱七人宛両町より罷出申候、御 銭之義も右二準し、罷出候人数、

御能拝見二罷出候人数

一拾七人

内七人、代地小松町、音羽町、福島町、正木町より罷出申候 但、南大工町之儀は前書申上候通、御用地二被召上、代地不 足地之分小松町、音羽町、福島町、正木町二而被下置候二付、 御能择見之節も、南大工町人数江小松町より三人、音羽町よ 
り武人、正木町より壱人、福島町より壱人、元地南大工町江 相加り罷出申候、尤御銭拾八貫文被下置候様、壱貫文月行事 分引、残而拾七貫文之内、右足シ地町々江六拾四間余、割合 を以割渡申候

右之通御尋二付申上候、已上

宝暦十三年未五月

$\begin{array}{lllll}\text { 南大工町 } & \text { 月行事 } & \text { 市郎兵衛 } & \text { 名主 } & \text { 藤五郎 } \\ \text { 小松町 } & \text { 月行事 } & \text { 市郎兵衛 } & \text { 名主 } & \text { 孫左衛門 } \\ \text { 音羽町 } & \text { 月行事 } & \text { 市郎左兵衛 } & \text { 名主 } & \text { 孫左衛門 } \\ \text { 福島町 } & \text { 月行事 } & \text { 利兵衛 } & \text { 名主 } & \text { 亦兵衛 } \\ \text { 正木町 } & \text { 月行事 } & \text { 藤右衛門 } & \text { 名主 } & \text { 主 計 }\end{array}$

以書付申上候（後略）

まず、町奉行が喜多村を通じて年番名主に「御能拝見」に元地の 人数と代地の人数を加えて参したことがある町の有無を調べている。 1 条は、町奉行の問いに対する書き付けで、南大工町の成立経緯及 びそれに伴う「御能择見」の人数分配が書かれている。最後には、 南大工町に分配された 17 人の分け方が出されている。

以上の史料からは、足し地である 4 個所の町の元地は元大工町で はなく、南大工町であることが確認できる。元大工町が一定の部分 を公収され南大工町を代地として与えられた時点で、元地と代地の 概念は一端切れる。そこから足りない分、すなわち 4 箅所の町は南 大工町の代地として与えられることになる。

ところが、「御能择見」に限っては、元大工町と南大工町が一緒に 能を楽しんでいることが窺える。[史料 8 ]を確認すると、「御能拝見」 には最大 34 人が認められる。それを元大工町と南大工町が均等に 17 人ずつとし、さらに南大工町の代地である 4 箇所の町においても、面 積の分人数を定めている。またこの際、配った御銭は 18 貫文で、月 行事の分を引いた 17 貫文を面積に応じて分けたことがわかる（表 1 )。 この史料からは、（1）元地と代地は一組になり、御能を捧見した こと、（2）御能拝見の人数は町の面積で決めたこと、（3）それに 伴う贈金も面積の割合に従って配られたことが読み取れる。

表 1 面積による拝見人数と御銭

(『安永三年小間附北方南方町鑑』、『江戸町触集成』より作成)

\begin{tabular}{|c|c|c|c|c|c|c|}
\hline \multicolumn{2}{|c|}{ 町名 } & \multicolumn{2}{|c|}{ 町総間数（京間） } & \multirow{3}{*}{\begin{tabular}{|l} 
足地の \\
間数割合
\end{tabular}} & \multirow{3}{*}{$\begin{array}{r}\begin{array}{r}\text { 拝見 } \\
\text { 人数 }\end{array} \\
17\end{array}$} & \multirow{3}{*}{$\begin{array}{r}\text { 推定 } \\
\text { 御銭 } \\
8 \text { 貫 } \\
500 \text { 出 }\end{array}$} \\
\hline \multirow{2}{*}{$\begin{array}{l}\text { 元 } \\
\text { 地 }\end{array}$} & \multirow[t]{2}{*}{ 元南大工町 } & 全体 & 165 間 3 尺 5 寸 & & & \\
\hline & & 代地 & - & & & \\
\hline \multirow{2}{*}{$\begin{array}{l}\text { 代 } \\
\text { 地 }\end{array}$} & \multirow[t]{2}{*}{ 南大工町 } & 全体 & 96 間 2 尺 9 寸 5 分 & & \multirow{2}{*}{10} & \multirow{2}{*}{5 貫 } \\
\hline & & 代地 & 92 間 5 尺 7 寸 5 分 & & & \\
\hline & 小松町 & 全体 & 42 間 1 尺 8 寸 8 分 & $0-11$ & 8 & 1 貫 \\
\hline & & 足地 & 26 間 3 尺 5 寸 3 分 & 0.41 & o & 500 両 \\
\hline & 音羽町 & 全体 & 36 間 9 寸 5 分 & - 27 & & \\
\hline 足 & & 足地 & 24 間 1 尺 & 0.31 & 2 & 1 貝 \\
\hline 地 & 福島町 & 全体 & 39 間 3 尺 9 寸 5 分 & 0 & 1 & 500 雨 \\
\hline & & 足地 & 9 間 2 尺 2 寸 4 分 & 0.14 & 1 & 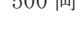 \\
\hline & 正木町 & 全体 & 44 間 3 寸 & 008 & 1 & 500 雨 \\
\hline & & 足地 & 4 間 6 尺 4 寸 3 分 & 0.08 & 1 & 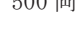 \\
\hline 合言 & & & & 1.00 & 34 人 & 17 貫文 \\
\hline
\end{tabular}

\section{5. むすびにかえて}

江戸の町中は火事により火除明地を設けながら、数多い代地を生 み出した。明地と代地により、江戸の都市空間は再編成されつつ、 土地の性格も変えていた。再編成の過程で一つの町はいくつかの代 地や性格の異なる空間で構成されることになる。このような現象は 火事という災害を契機に、火除地という幕府が意図している都市イ ンフラの論理と町人の所有意志が衝突しながら現れたと思われる。

町地が火災で明地になり、代わりに代地を与えられるという土地 の入れ替えを繰り返しながら、江戸は巨大都市化していた。このよ うな都市の変化の中、町人達の生活はいかなるものであったのか。 本稿では、役と「御能拝見」の分析を通じて、江戸の都市空間が再 編成される中での元地と代地の関係について追究した。

元地と代地の関係においては、町という空間を超えて町人達は役 を果たし、一組になって御能拝見」を楽しんでいたことがわかる。 都市空間が分離されても、町人達には従来の社会構造を維持しよう とする傾向が見られる。

注

1) 吉田伸之『近世巨大都市の社会構造』(東京大学出版会、1991 年)

2) 高野家は南伝馬町二町目、同三町目、同三町目新道、南塗師町、南鞘町、 松川町一町目・二町目、通三町目代地、南伝馬町三町目で下町として赤坂 伝馬町五町・赤坂田町五町を支配した名主で、この記録は元禄期から正徳 期までの日記である。

3）先行研究では、双川喜文氏『近世の土地私有制』(技報堂、1980 年)、片倉比 佐子『江戸の土地問題』(同成社、2004 年)、岩淵令治『土地所有史』(山川出 版社、2002 年)、北島正元『土地制度史』(山川出版社、1974 年)、吉田伸之 『近世都市社会の身分構造』(東京大学出版会、1998 年) が挙げられる。

4) 土方晋『江戸時代の江戸の税制と明治六年地租改正法公布』(税務経理協会、 2004 年) では江戸の役について論じている。

5）『旧幕府引継書』には「明地之部」があり、享保、明和、安永、天保の四編が ある $(1716-1867)$ 。享保期は上ノ上、上ノ下、下の三冊に分かれている。「明 地之部」には明地の成立背景、時期、利用形態、禁止内容、境界装置、入用、 支配主体などが記入されている。享保期から天保期（1716-1867）までの「明 地之部」を読むと江戸中期から末期までの明地の変遷が読み取れると期待する。 享保期の「明地之部」構成は、明地に立てられた札文言及び札立が書かれてい る「明地之部」と実際の内容が書かれている「覚」からなる。覚」には時順て 明地の事が書かれていて、元文五年 (1740) には江戸全体の明地の調べがある。 これで、明地の対象地は想定できる。(国立国会図書館所蔵)

6）『安永三年小間附北方南方町鑑』(東京都公文書館、1990 年)、江戸町鑑怔、 江戸も市政名鑑、あるいは市政要覧としての性格をもち、武鑑と同様に每 年のように改訂し、刊行された。内容は、町奉行所関係（町年寄を含む） の名簿、名主支配付 (名主名とその支配町名) 、町火消関係記事、町尽 (町 名小名・坂・橋・堀などの名寄) などである。

7) 南和男『江戸の社会構造』(塙書房、1969 年) pp . 344-345。

8)『安永三年江戸町鑑下』(東京都公文書館、1990 年) pp . 1-2。

9)『安永三年小間附北方南方町鑑上』(東京都公文書館、1990 年） p . 154。

10）『御府内備考第一巻』(「大日本地誌大系 14 、雄山閣、1958 年） p . 170。

11) 『御府内備考第一巻』(「大日本地誌大系 14 、雄山閣、1958 年) p . 168。

12）『享保撰要類集』、明地之部上ノ上、九 (国立国会図書館所蔵「幕府引継書」)。

13）『享保撰要類集』、明地之部上ノ上、一五 (国立国会図書館所蔵[幕府引継書」)。

14）『享保撰要類集』、明地之部上八下、二六 (国立国会図書館所蔵「幕府引継書」)。

15）塗家というのは、建物の正面が土壁で塗り込められている町屋であるが 土壁の厚さが本格的な土藏造のものより薄く、開口部にも防火戸が入っ ていないものが多い。(大島信道「東京人」1995 年、no91、p . 69)

16）『安永三年江戸町鑑下』（東京都公文書館、1990 年） p . 24。

17）『江戸城下変遷絵図集第七巻』(原書房、1986 年) p . 5。

18）「足し地」とは、町が公収され代地が与えられた際、再び与えられた足 りない分の土地である。「足し地」の場合、いくつかの町の足し地を合 わせて、一つの町として成立される。町名は一つであるが、役及び町人 の生活全般は元地に基づいて行われる。

19）『江戸町触集成第四巻』五八三○ (近世史料研究会編、1996 年) pp . 132-137。

20）青木宏一郎『江戸庶民の楽しみ』(中央公論新社、2006 年)、川崎房五郎 「江戸の古町の町々と御能拝見」(『選挙』37、1984 年 1 月) pp . 18-22。

21）『江戸町触集成第六巻』七六一三 (近世史料研究会編、1996 年) pp . 260-264。 